\title{
Improvement of loamy sand soil and potato plant productivity under integrated organic and inorganic nitrogen fertilizers
}

\author{
Ahmed Azza R. ${ }^{\mathrm{a}^{*}}$, Shahien M.M. ${ }^{\mathrm{b}}$ \\ ${ }^{a}$ Soil, Water and Environment Research Institute, Agriculture Research Center, Giza, Egypt \\ ${ }^{b}$ Department of Vegetable Crops, Faculty of Agriculture, Cairo University, Giza, Egypt
}

\begin{abstract}
Two experiments were conducted at EL Khattatba region - Egypt during two winter seasons to evaluate the effect of single or combined application of organic nitrogen fertilizer farmyard manure, chicken manure and compost with inorganic nitrogen fertilizer (ammonium nitrate 33.5\%) on soil properties and identify the best rates on potato tuber yield and quality. Five ratio of nitrogen fertilizers were $100 \%$ nitrogen mineral fertilizer, $75 \%$ nitrogen mineral $+25 \%$ nitrogen organic fertilizer, $50 \%$ nitrogen mineral $+50 \%$ nitrogen organic fertilizer, $25 \%$ nitrogen mineral $+75 \%$ nitrogen organic fertilizer and $100 \%$ nitrogen organic fertilizer. Organic carbon content was increased significantly with applied organic fertilizers compared to mineral fertilizer. Soil total nitrogen ascertained highest values by applying mineral $\mathrm{N}$ fertilizer than organic fertilizer treatments. C: $\mathrm{N}$ ratio of soil significantly increased with organic fertilizers and $100 \% \mathrm{~N}$ organic fertilizer treatment was superiority for raising C:N ratio of soil. $100 \% \mathrm{~N}$ mineral fertilizer treatment had depressive effects on C: $\mathrm{N}$ which were lower than tested soil. Both $\mathrm{pH}$ and bulk density were significantly decreased by applying organic fertilizers. $100 \% \mathrm{~N}$ chicken manure treatment was recorded maximum decreasing. Each of E.C, $\mathrm{K}_{\mathrm{h}}$ and available water were influenced by applying organic fertilizers types. $100 \% \mathrm{~N}$ organic fertilizers were ascertained the significant effect for each EC, $\mathrm{K}_{\mathrm{h}}$ and available water compared to other rates or $100 \% \mathrm{~N}$ mineral fertilizer. The highest tuber yield was ascertained by applying the treatment $25 \% \mathrm{~N}$ organic fertilizer with $75 \% \mathrm{~N}$ mineral for each season. Carbohydrate\% was decreased with raising the rates of organic fertilizers and the maximum values were recorded at $100 \% \mathrm{~N}$ mineral. There was irregular trend for tuber specific gravity with organic fertilizers or their rates for both seasons. The relation between NO3-N ion, N\% content in tuber and Total $\mathrm{N} \%$ in soil indicated that increasing ratio of organic fertilizers decreased the NO3-N ion in tuber.
\end{abstract}

Keywords: loamy sand soil, organic fertilizer, mineral fertilizers, potatoes, carbohydrate, nitrate ion.

\footnotetext{
* Corresponding author:

E-mail address: dr_azza_rashad@hotmail.com
} 


\section{Introduction}

Soil in Egypt are very poor in their organic matter content which fluctuates between $0.1-2.5$. Organic and mineral fertilization improves light-textured soils, physical properties, available water and warmth regime. Systematic fertilization not only increases crop yield but also alters its quality, sustain soil health and its fertility (Shaker Nesreen et al., 2015). The current global scenario firmly emphasizes the need to adopt eco-friendly agricultural practices for sustainable agricultural production (Ashraful Islam et al., 2017). The cost of inorganic fertilizers is increasing enormously, to the extent that they are out of reach for small and marginal farmers. The effect of organic manure on plant behavior is not just a matter of nutrients supply and organic materials influence physio, chemical and biological characteristics of soil which in turn influence development of plants. Integrated use of chemical fertilizers and organic fertilizers may be an approach for sustainable production of crops. Application of farmyard manure improved the productivity of potato plants and it was increased with increasing of farmyard manure levels up to $20 \mathrm{~m} 3 / \mathrm{fed}$ $\left(1\right.$ feddan $=4200$ square metres $\left(\mathrm{m}^{2}\right)=$ 0.42 hectares $=1.038$ acres) $($ Ahmed et al., 2015). This may improve the efficiency of chemical fertilizers and thus reduce their use (Baniuniene and Zekaite, 2008). The potato is the world's most important root and tuber crop worldwide. It is grown in more than 125 countries and consumed almost daily by more than a billion people. Hundreds of millions of people in developing countries depend on potatoes for their survival. Potato cultivation is expanding strongly in the developing country, where the potato's ease of cultivation and nutritive content has made it a valuable food security and cash crop for millions of farmers. Developing countries are now the world's biggest producers, importers of potatoes or potato products (Girma et al., 2017). The objectives of present study were to evaluate effect of single or combined application of farmyard manure, chicken manure $(\mathrm{CH})$ or compost $(\mathrm{CO})$ with inorganic nitrogen fertilizer (ammonium nitrate $33.5 \%$ ) on some soil properties and identify the best levels in yield production and use efficiency in response to different rate of the applied organic and inorganic nitrogen fertilizer.

\section{Materials and methods}

Two field experiments were conducted at newly reclaimed loamy sand soil in ElKhatataba region, El-Monofia governorate, Egypt, during two successive winter seasons of 2013/14 and 2014/15. Some initial physical and chemical properties of tested soil are showing in Table (1) according to (Black, 1983).

\subsection{Nitrogen fertilizer sources}

Different nitrogen fertilizer sources were used as follows:

\section{Organic fertilisers (OF)}

- Farmyard manure (FYM).

- Chicken manure $(\mathrm{CH})$.

- Compost fertiliser (CO). 


\section{Mineral nitrogen fertiliser (Min)}

- Ammonium nitrate $(33.5 \%)$

The chemical characteristics of organic fertilizers were determined according to Black (1965) are presented in Table (2) was average two seasons.

\subsection{The experimental design and treatments}

Split plot design was used with three replicates. Nitrogen fertilizer types either organic or mineral fertilizers were devoted to the main plots, while the fertilizers rates were assigned to subplots. To achieve the purpose of present study potatoes (Diamount $c v$.) was chosen from local source in Egypt. Five nitrogen fertilizer sources were applied on the base of nitrogen recommended doses for potatoes plant $\left(150 \mathrm{~kg} \mathrm{~N}^{\mathrm{fed}}{ }^{-1}\right)(1$ feddan $=4200$ square metres $\left(\mathrm{m}^{2}\right)=0.42$ hectares $=1.038$ acres) as following: $100 \%$ recommended $\mathrm{N}$ in mineral fertilizer (min) form, $75 \% \mathrm{~N}$ min. plus $25 \% \mathrm{~N} \mathrm{OF}$, $50 \% \mathrm{~N}$ min plus $50 \% \mathrm{~N} . \mathrm{OF}, 25 \% \mathrm{~N}$ min plus $75 \%$ NOF and $100 \% \mathrm{~N}$ OF. The organic nitrogen fertilizers were added at preparation of soil. The plot area was $30 \mathrm{~m} 2$ with 12 lines in each plot. Calcium super phosphate $\left(15.5 \% \quad \mathrm{P}_{2} \mathrm{O}_{5}\right)$ at a recommended dose of $400 \mathrm{~kg} /$ fed was applied before soil tillage. Mineral nitrogen fertilizer was applied through drip irrigation system (fertigation). Also, potassium sulphate $\left(48 \% \mathrm{~K}_{2} \mathrm{O}\right)$ at $200 \mathrm{~kg} /$ fed level was applied through drip irrigation Potato tuber pieces were planted at $25 \mathrm{~cm}$ distance in $10 \mathrm{~cm}$ of furrow depth at the rate of $1300 \mathrm{~kg}$ fed- 1 on $20^{\text {th }}$ November in both seasons.

Table (1): Some physical and chemical properties of initial soil for two winter seasons 2013/14 and 2014/15.

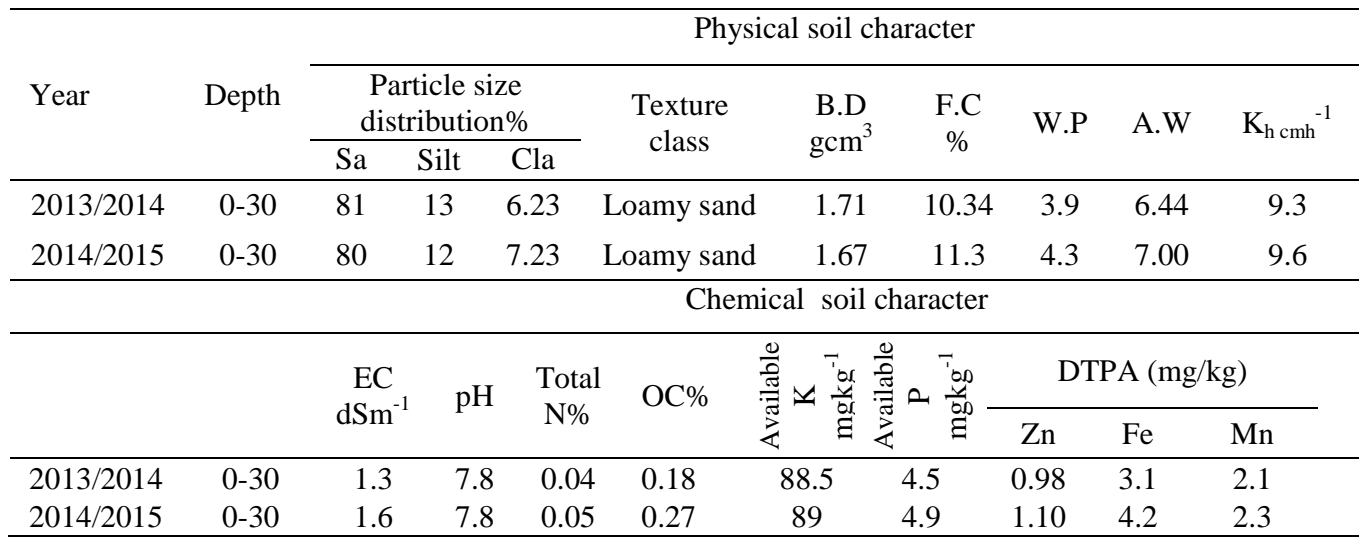


Table (2): Some chemical properties of organic fertilizers.

\begin{tabular}{|c|c|c|c|c|c|c|c|c|c|c|}
\hline $\begin{array}{l}\text { Organic } \\
\text { fertilizers }\end{array}$ & $\begin{array}{l}\mathrm{pH} \\
1: 10\end{array}$ & 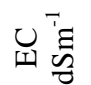 & $\begin{array}{l}\mathrm{OC} \\
\%\end{array}$ & $\begin{array}{l}\text { Total } \\
\mathrm{N} \%\end{array}$ & $\begin{array}{l}\text { Total } \\
\mathrm{K} \%\end{array}$ & $\begin{array}{c}\text { Available P } \\
\text { (ppm) }\end{array}$ & $\begin{array}{l}\mathrm{C} / \mathrm{N} \\
\text { ratio }\end{array}$ & $\begin{array}{c}\mathrm{Fe} \\
(\mathrm{ppm})\end{array}$ & $\begin{array}{c}\mathrm{Zn} \\
(\mathrm{ppm})\end{array}$ & $\begin{array}{c}\mathrm{Mn} \\
(\mathrm{ppm})\end{array}$ \\
\hline FYM & 6.5 & 9.9 & 36.03 & 2.55 & 2.26 & 180.7 & $14: 1$ & 42.95 & 30.55 & 46.3 \\
\hline $\mathrm{CH}$ & 7.14 & 3.7 & 36.06 & 3.14 & 2.65 & 342.3 & $11.5: 1$ & 27.80 & 55.90 & 63.15 \\
\hline Comp & 7.54 & 2.5 & 34.49 & 2.16 & 1.17 & 187.3 & $16: 1$ & 31.2 & 19.7 & 53.5 \\
\hline
\end{tabular}

\subsection{Soil analysis before planting and} after harvest

Mechanical analysis was determined according to Piper (1950). Soil pH and electrical conductivity (EC) and available water $\%$ were determined as described by Richards (1954). Organic carbon (OC \%) was determined according to Walkley and Black method as described by Hesse (1971). Soil bulk density and hydraulic conductivity were determined according to Black (1983). Total soil nitrogen was determined according to Bremner et al. (1982). The $\mathrm{C} / \mathrm{N}$ ratio was calculated as

$\mathrm{C} / \mathrm{N}$ ratio $=0 . \mathrm{C} \%$ of soil $/$ Total $\mathrm{N} \%$ of soil.

\subsection{Chemical analysis of plant}

Samples of tubers from three potato plants were chosen randomly in both two seasons after 110 days (harvest stage). Samples were oven dried at $70^{\circ} \mathrm{C}$ till constant weight then were ground to a fine powder to determine:

- The percentages of total nitrogen by Kjeldahl method as Hesse (1971).

- Tuber Quality Parameters at harvest stage

- Total Nitrate.
- The $\mathrm{NO}_{3}-\mathrm{N}$ concentration was determined according to Ulrich et al. (1959).

- Carbohydrate content (\%) according to Herbert (1971)

- Specific gravity: it was determined according to the methods of Smith (1975).

The tuber were weighted in air and then in water.

Specific gravity (S.g.) $=\frac{\text { Weight in air }}{\text { Weight in air }- \text { Weight in water }}$

\subsection{Statistical analysis}

Obtained data was statistically analyzed using MSTAT program (1990).

\section{Results and Discussion}

\subsection{Organic carbon percent (OC \%)}

The effect of applied different nitrogen fertilizer sources on soil OC\% is presented in Table (3). Date revealed that, applying $\mathrm{CH}, \mathrm{FYM}$ or $\mathrm{CO}$ were associated with an increase of soil OC \% than the initial data one in both seasons. The highest mean values of soil OC\% 
(2.1 and $2.18 \%)$ were recorded in chicken manure treatment. The difference among the mean values of soil OC content due to applying different nitrogen fertilizer sources were significantly. Similar results were obtained by Ahmed Azza et al. (2012) reported that the inclusion of manure in the fertilization schedule improved the organic carbon status and available $\mathrm{N}, \mathrm{P}, \mathrm{K}$ and $\mathrm{S}$ in soils so sustaining soil health. Data in Table (3) revealed that soil OC \% increased by increasing the rates of organic fertilization till the highest (100\% OF + Zero MIN). Also, it was noticed, that soil OC\% due to applying $100 \%$ mineral nitrogen fertilizer decreased compared to initial OC\% which cause soil deterioration. These findings were in harmony by Ahmed Azza et al. (2011) and Sadaf Khan (2011).

Table (3): Effect treatments on organic carbon percent OC\% and Total nitrogen N\% after two winter of 2013/14 and 2014/15.

\begin{tabular}{|c|c|c|c|c|c|c|c|c|c|}
\hline \multirow{3}{*}{$\mathrm{OF}(\mathrm{N} \%)$} & \multirow{3}{*}{$\min (\mathrm{N} \%)$} & \multicolumn{3}{|c|}{$\mathrm{O} . \mathrm{C} \%$} & \multirow{3}{*}{$\begin{array}{c}\text { mean } \\
\text { rate }\end{array}$} & \multirow{2}{*}{\multicolumn{3}{|c|}{$\frac{\text { O.C\% }}{2014 / 15 .}$}} & \multirow{3}{*}{$\begin{array}{c}\text { mean } \\
\text { rate }\end{array}$} \\
\hline & & \multicolumn{3}{|c|}{$2013 / 14$} & & & & & \\
\hline & & FYM & $\mathrm{CH}$ & $\mathrm{CO}$ & & FYM & $\mathrm{CH}$ & $\mathrm{CO}$ & \\
\hline$\overline{\text { Zero }}$ & 100 & $0.17^{\mathrm{f}}$ & $0.17^{f}$ & $0.17^{f}$ & $0.17^{\mathrm{E}}$ & $0.19^{i}$ & $0.19^{i}$ & $0.19^{i}$ & $0.19^{\mathrm{E}}$ \\
\hline 25 & 75 & $1.03^{\mathrm{d}}$ & $1.20^{\mathrm{cd}}$ & $0.46^{\mathrm{e}}$ & $0.90^{\mathrm{D}}$ & $1.62^{\mathrm{e}}$ & $1.65^{\mathrm{e}}$ & $0.51^{\mathrm{h}}$ & $1.26^{\mathrm{D}}$ \\
\hline 50 & 50 & $1.17^{\mathrm{cd}}$ & $1.32^{\mathrm{c}}$ & $0.58^{\mathrm{e}}$ & $1.02^{\mathrm{C}}$ & $1.75^{\mathrm{c}-\mathrm{e}}$ & $1.69^{\mathrm{de}}$ & $0.93^{\mathrm{g}}$ & $1.46^{\mathrm{C}}$ \\
\hline 75 & 25 & $1.76^{\mathrm{b}}$ & $1.85^{\mathrm{b}}$ & $1.06^{\mathrm{d}}$ & $1.56^{\mathrm{B}}$ & $1.88^{\mathrm{b}-\mathrm{d}}$ & $2.06^{\mathrm{ab}}$ & $1.27^{\mathrm{f}}$ & $1.74^{\mathrm{B}}$ \\
\hline 100 & Zero & $1.90^{\mathrm{b}}$ & $2.10^{\mathrm{a}}$ & $1.28^{\mathrm{c}}$ & $1.76^{\mathrm{A}}$ & $1.98^{\mathrm{a}-\mathrm{c}}$ & $2.18^{\mathrm{a}}$ & $1.63^{\mathrm{e}}$ & $1.93^{\mathrm{A}}$ \\
\hline \multicolumn{2}{|l|}{ Mean (OF) } & $1.21^{\mathrm{B}}$ & $1.33^{\mathrm{A}}$ & $0.71^{\mathrm{C}}$ & & $1.48^{\mathrm{A}}$ & $1.55^{\mathrm{A}}$ & $0.91^{\mathrm{B}}$ & \\
\hline $\mathrm{OF}(\mathrm{N} \%)$ & $\min (\mathrm{N} \%)$ & & $\mathrm{N} \%$ & & & & $\mathrm{~N} \%$ & & \\
\hline Zero & 100 & $0.33^{\mathrm{a}}$ & $0.33^{\mathrm{a}}$ & $0.33^{\mathrm{a}}$ & $0.33^{\mathrm{A}}$ & $0.39^{\mathrm{a}}$ & $0.39^{\mathrm{a}}$ & $0.39^{\mathrm{a}}$ & $0.39^{\mathrm{A}}$ \\
\hline 25 & 75 & $0.12^{\mathrm{de}}$ & $0.12 \mathrm{~d}^{\mathrm{e}}$ & $0.09^{\mathrm{e}}$ & $0.11^{\mathrm{C}}$ & $0.13^{\mathrm{b}-\mathrm{d}}$ & $0.13^{b-d}$ & $0.10^{\mathrm{d}}$ & $0.12^{\mathrm{B}}$ \\
\hline 50 & 50 & $0.10^{\mathrm{de}}$ & $0.14^{\mathrm{b}-\mathrm{e}}$ & $0.09^{\mathrm{e}}$ & $0.11^{\mathrm{C}}$ & $0.13^{\mathrm{b}-\mathrm{d}}$ & $0.14^{\mathrm{bc}}$ & $0.11^{\mathrm{cd}}$ & $0.13^{\mathrm{B}}$ \\
\hline 75 & 25 & $0.13^{\mathrm{c}-\mathrm{e}}$ & $0.16^{\mathrm{b}-\mathrm{d}}$ & $0.11^{\mathrm{de}}$ & $0.13^{\mathrm{B}}$ & $0.14^{\mathrm{bc}}$ & $0.14^{\mathrm{bc}}$ & $0.12^{\mathrm{b}-\mathrm{d}}$ & $0.13^{\mathrm{B}}$ \\
\hline 100 & Zero & $0.13^{\mathrm{c}-\mathrm{e}}$ & $0.18^{\mathrm{bc}}$ & $0.12^{\mathrm{de}}$ & $0.14^{\mathrm{B}}$ & $0.14^{\mathrm{bc}}$ & $0.15^{\mathrm{b}}$ & $0.13^{\mathrm{b}-\mathrm{d}}$ & $0.14^{\mathrm{B}}$ \\
\hline Mean $(\mathrm{OF}$ & & $0.16^{\mathrm{B}}$ & $0.19^{\mathrm{A}}$ & $0.15^{\mathrm{B}}$ & & $0.19^{\mathrm{A}}$ & $0.19^{\mathrm{A}}$ & $0.17^{\mathrm{B}}$ & \\
\hline
\end{tabular}

$\overline{\mathrm{OF}}=$ organic fertilizer, $\min =$ mineral fertilizer, $\mathrm{FYM}=$ farmyard manure, $\mathrm{CH}=$ chicken manure, $\mathrm{CO}=$ compost.

\subsection{Total nitrogen percent}

Data present in Table (3) showed the application of different type of nitrogen fertilizers were significant increased the total N\% compared the initial one. The mineral nitrogen fertilizer ( $\mathrm{min})$ was ascertained the maximum mean values of total $\mathrm{N} \%\left(0.33\right.$ and $0.39 \% \mathrm{~N}$ after $1^{\text {st }}$ and $2^{\text {nd }}$ season, respectively. Data in Table (3) revealed that treatment of $100 \% \mathrm{~N}$ of all organic nitrogen fertilizers recorded the highest mean values of total $\mathrm{N} \%$ in soil.

\subsection{Organic carbon to nitrogen ratio $(C$ : N ratio)}

Data in Figure $(1 \mathrm{a} \& b)$ showed that the value of $\mathrm{C} / \mathrm{N}$ ratio of untreated soil equal to 4.5 and 5.4. Application of mineral nitrogen fertilizer caused a significant 
decrease in $\mathrm{C}: \mathrm{N}$ ratio that became 0.51 and 0.48 for the corresponding season. On the other hand, adding different organic nitrogen fertilizers increased significantly the mean values of $\mathrm{C}: \mathrm{N}$ ratio in the descending order as FYM (9.3)> $\mathrm{CH}$ (8.7)> CO (6.49). Mineral fertilization had depressive effect on $\mathrm{C}: \mathrm{N}$ ratio. The dose $100 \%$ organic fertilizers for all types were ascertained the highest mean values of $\mathrm{C}: \mathrm{N}$ which were 12.36 and 13.68 for $1^{\text {st }}$ and $2^{\text {nd }}$ seasons, respectively. Also, it was noticed that, the treatment of chicken manure induce an initial increase at dose $25 \%$ organic fertilizer which was equal to10.0 and 12.41 for $1^{\text {st }}$ and $2^{\text {nd }}$ seasons, respectively. Instead the dose $50 \%$ caused a reduction in C:N ratio fall to 9.4 and 12.07. Moreover, the mean values of $\mathrm{C}: \mathrm{N}$ ratio at dose $75 \% \mathrm{~N}$ and $100 \% \mathrm{~N}$ of $\mathrm{CH}$ manure treatments were almost 11.56 and 11.79 also 14.3 and 14.43 in $1^{\text {st }}$ and $2^{\text {nd }}$ seasons, respectively, indicating of the organic fertilizer.

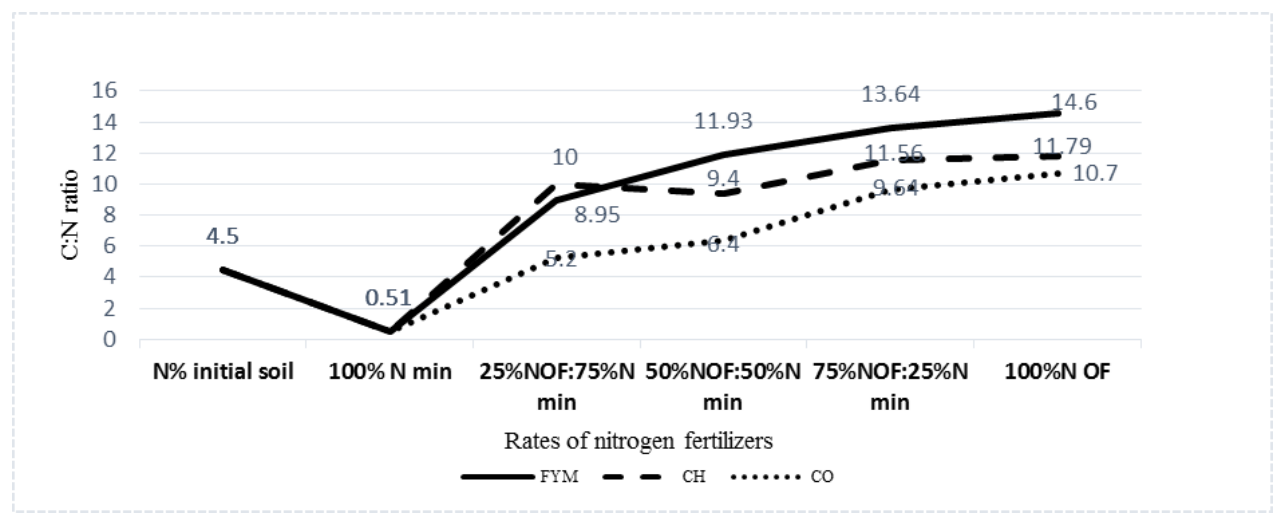

Figure (1-a): Effect of treatments on C:N ratio of soil after winter 2013/14.

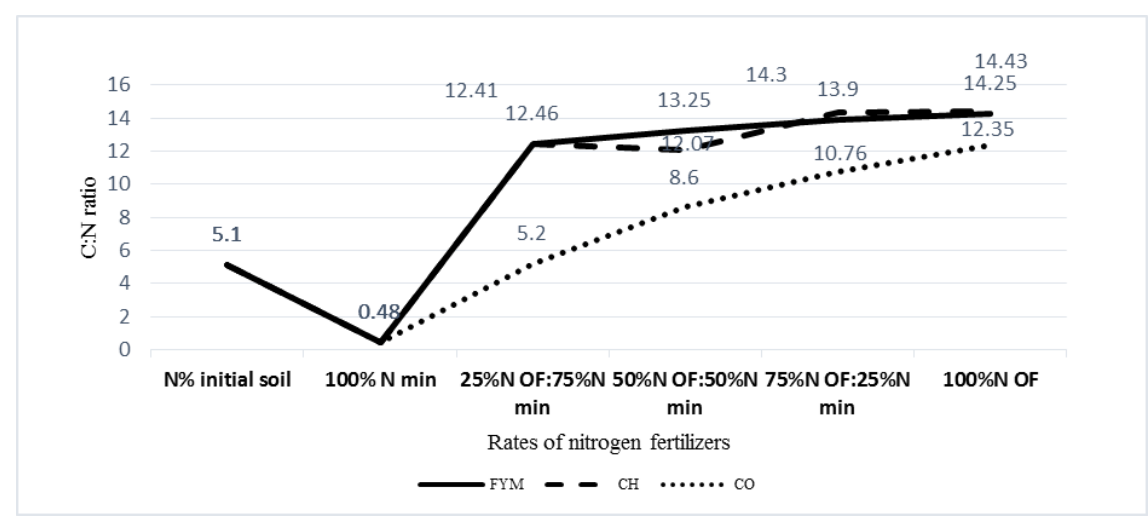

Figure (1-b): Effect of treatments on C:N ratio of soil after winter 2014/15. 


\subsection{Soil pH}

Table (4) revealed that the effect of different organic nitrogen fertilizers sources on soil $\mathrm{pH}$ was insignificant in both seasons. While the mean values of soil $\mathrm{pH}$ were decreased significantly by applying different organic nitrogen fertilizers sources compared to the initial one in both seasons. The values of $\mathrm{pH}$ decreased from 7.8 to $7.20,7.10$ and 7.2 by applying FYM, $\mathrm{CH}$ and Comp, respectively in the $1^{\text {st }}$ season while they were 7.8 to $7.63,7.52,7.64$ in the $2^{\text {nd }}$ one for the corresponding treatments This result reported by Ahmed Azza (2013). From above mentioned date, adding organic fertilizers $(\mathrm{OF})$ caused a reduction in soil $\mathrm{pH}$. The highest rates of organic fertilization, the lowest soil $\mathrm{pH}$ values. The lowest values of soil $\mathrm{pH}$ were 7.027 and 7.33 in $1^{\text {st }}$ and $2^{\text {nd }}$ seasons respectively in the treatment $100 \% \mathrm{OF}+$ Zero MIN. The minimum soil $\mathrm{pH}$ values of 7.01 and 7.12 were recorded in the treatment of $\mathrm{CH}$ manure at $100 \% \mathrm{OF}$ in $1^{\text {st }}$ and $2^{\text {nd }}$ seasons, respectively.

\subsection{Soil salinity $(E C)$}

Table (5) showed the effect of different nitrogen fertilizers after two winter sseasons on soil salinity. EC value was increased by adding different organic fertilizers from $1.3 \mathrm{dSm}^{-1}$ (initial soil) to1.44, 26, 2.63 and 2.17 in $1^{\text {st }}$ year and to $1.492 .71,2.61$ and 2.02 in $2^{\text {nd }}$ year in mineral nitrogen fertilizers, FYM, $\mathrm{CH}$ and Comp, respectively. It is obvious that EC values were rather higher with FYM than $\mathrm{CH}$ and Comp in both seasons. The increasing rates of organic fertilizers (OF) increase the means values of EC significantly in both seasons. The highest value of EC was recorded with $100 \%$ of each type of organic nitrogen fertilizers in both seasons.

Table (4): Effect of treatments on soil pH after two winter of 2013/14 and 2014/15.

\begin{tabular}{|c|c|c|c|c|c|c|c|c|c|}
\hline \multicolumn{2}{|c|}{ Treatments } & \multicolumn{3}{|c|}{$\mathrm{pH} 2013 / 14$} & \multirow{2}{*}{$\begin{array}{l}\text { mean } \\
\text { (rate) }\end{array}$} & \multicolumn{3}{|c|}{$\mathrm{pH} 2014 / 15$} & \multirow{2}{*}{$\begin{array}{l}\text { mean } \\
\text { (rate) }\end{array}$} \\
\hline $\mathrm{OF}(\mathrm{N} \%)$ & $\min (\mathrm{N} \%)$ & FYM & $\mathrm{CH}$ & $\mathrm{CO}$ & & FYM & $\mathrm{CH}$ & $\mathrm{CO}$ & \\
\hline Zero & 100 & $7.90^{\mathrm{a}}$ & $7.90^{\mathrm{a}}$ & $7.90^{\mathrm{a}}$ & $7.90^{\mathrm{A}}$ & $7.95^{\mathrm{a}}$ & $7.95^{\mathrm{a}}$ & $7.95^{\mathrm{a}}$ & $7.95^{\mathrm{A}}$ \\
\hline 25 & 75 & $7.45^{\mathrm{b}}$ & $7.25^{\mathrm{c}}$ & $7.43^{\mathrm{b}}$ & $7.38^{\mathrm{B}}$ & $7.78^{\mathrm{bc}}$ & $7.76^{c}$ & $7.78^{\mathrm{bc}}$ & $7.77^{\mathrm{B}}$ \\
\hline 50 & 50 & $7.15^{\mathrm{cd}}$ & $7.12^{c}$ & $7.12^{c}$ & $7.13^{C}$ & $7.70^{\mathrm{cd}}$ & $7.66^{\mathrm{cd}}$ & $7.70^{\mathrm{cd}}$ & $7.69^{\mathrm{BC}}$ \\
\hline 75 & 25 & $7.14^{\mathrm{cd}}$ & $7.02^{\mathrm{de}}$ & $7.08^{\mathrm{d}}$ & $7.08^{\mathrm{C}}$ & $7.62^{\mathrm{cd}}$ & $7.53^{\mathrm{de}}$ & $7.64^{\mathrm{cd}}$ & $7.60^{\mathrm{C}}$ \\
\hline 100 & Zero & $7.05^{\mathrm{de}}$ & $7.01^{\mathrm{de}}$ & $7.02^{\mathrm{de}}$ & $7.03^{C}$ & $7.45^{\mathrm{e}}$ & $7.12^{f}$ & $7.43^{\mathrm{e}}$ & $7.33^{\mathrm{D}}$ \\
\hline Mean (OF) & & $7.34^{\mathrm{A}}$ & $7.26^{\mathrm{B}}$ & $7.31^{\mathrm{A}}$ & & $7.70^{\mathrm{A}}$ & $7.60^{\mathrm{B}}$ & $7.70^{\mathrm{A}}$ & \\
\hline
\end{tabular}

\subsection{Bulk density ( $\mathrm{gcm}-3)$}

Data presented in Table (6) showed that the application of comp as organic nitrogen fertilizers decreases the mean values of bulk density significantly compared to FYM and $\mathrm{CH}$ treatments in both seasons. This data was harmony with that reported by El-Fayomy and Hammed (2001) and Hati et al. (2006). The 
minimum bulk density values of 1.52 and $1.40 \mathrm{~g} / \mathrm{cm} 3$ were recorded at $100 \%$ organic fertilizer in $1^{\text {st }}$ and $2^{\text {nd }}$ season, respectively. This data was harmony with that reported by Sadaf and Khan (2011) and Ahmed Azza (2013).

Table (5): Effect of treatment on EC of soil after two winter seasons 2013/2014 and 2014/2015.

\begin{tabular}{|c|c|c|c|c|c|c|c|c|c|}
\hline \multirow{2}{*}{\multicolumn{2}{|c|}{ Treatments }} & \multirow{2}{*}{\multicolumn{3}{|c|}{$\frac{\text { E.C dSm }^{-1}}{2013 / 14}$}} & \multirow{3}{*}{ mean rate } & \multirow{2}{*}{\multicolumn{3}{|c|}{ E.C dSm ${ }^{-1}$}} & \multirow{3}{*}{ mean rate } \\
\hline & & & & & & & & & \\
\hline $\mathrm{OF}(\mathrm{N} \%)$ & $\min (\mathrm{N} \%)$ & FYM & $\mathrm{CH}$ & $\mathrm{CO}$ & & FYM & $\mathrm{CH}$ & $\mathrm{CO}$ & \\
\hline Zero & 100 & $1.44^{\mathrm{f}}$ & $1.44^{\mathrm{f}}$ & $1.44^{\mathrm{f}}$ & $1.44^{\mathrm{E}}$ & $1.90^{\mathrm{e}}$ & $1.90^{\mathrm{e}}$ & $1.90^{\mathrm{e}}$ & $1.90^{\mathrm{D}}$ \\
\hline 25 & 75 & $1.53^{f}$ & $2.01^{\mathrm{e}}$ & $1.54^{\mathrm{f}}$ & $1.69^{\mathrm{D}}$ & $2.50^{\mathrm{d}}$ & $1.91^{\mathrm{e}}$ & $1.28^{\mathrm{f}}$ & $1.90^{\mathrm{D}}$ \\
\hline 50 & 50 & $2.02^{\mathrm{e}}$ & $2.95^{\mathrm{d}}$ & $1.54^{\mathrm{f}}$ & $2.17^{\mathrm{C}}$ & $2.94^{\mathrm{bc}}$ & $2.61^{\mathrm{cd}}$ & $1.64^{\mathrm{e}}$ & $2.40^{\mathrm{C}}$ \\
\hline 75 & 25 & $3.30^{\mathrm{c}}$ & $3.38^{c}$ & $2.14^{\mathrm{e}}$ & $2.94^{\mathrm{B}}$ & $3.33^{\mathrm{b}}$ & $2.98^{\mathrm{bc}}$ & $2.55^{\mathrm{d}}$ & $2.95^{\mathrm{B}}$ \\
\hline 100 & Zero & $4.80^{\mathrm{a}}$ & $3.35^{\mathrm{c}}$ & $4.19^{b}$ & $4.11^{\mathrm{A}}$ & $3.29^{\mathrm{b}}$ & $4.05^{\mathrm{a}}$ & $3.16^{\mathrm{b}}$ & $3.50^{\mathrm{A}}$ \\
\hline Mean (OF) & & $2.62^{\mathrm{A}}$ & $2.63^{\mathrm{A}}$ & $2.17^{\mathrm{B}}$ & & $2.79^{\mathrm{A}}$ & $2.69^{\mathrm{A}}$ & $2.11^{\mathrm{B}}$ & \\
\hline
\end{tabular}

Table (6): Effect of treatments on B.Dg cm${ }^{-3}$ after two winter seasons 2013/14 and 2014 and 15.

\begin{tabular}{|c|c|c|c|c|c|c|c|c|c|}
\hline \multicolumn{2}{|c|}{ Treatments } & \multicolumn{3}{|c|}{$\frac{\text { Bulk density } \mathrm{g} \mathrm{cm}^{-3}}{2013 / 14}$} & \multirow{2}{*}{$\begin{array}{l}\text { mean } \\
\text { rate }\end{array}$} & \multicolumn{3}{|c|}{$\begin{array}{c}\text { Bulk density } \mathrm{g} \mathrm{cm}^{-3} \\
\text { 2014and } 15\end{array}$} & \multirow{2}{*}{$\begin{array}{c}\text { mean } \\
\text { rate }\end{array}$} \\
\hline $\mathrm{OF}(\mathrm{N} \%)$ & $\min (\mathrm{N} \%)$ & FYM & $\mathrm{CH}$ & $\mathrm{CO}$ & & FYM & $\mathrm{CH}$ & $\mathrm{CO}$ & \\
\hline Zero & 100 & $1.70^{\mathrm{a}}$ & $1.70^{\mathrm{a}}$ & $1.70^{\mathrm{a}}$ & $1.70^{\mathrm{A}}$ & $1.69^{\mathrm{a}}$ & $1.69^{\mathrm{a}}$ & $1.69^{\mathrm{a}}$ & $1.69^{\mathrm{A}}$ \\
\hline 25 & 75 & $1.52^{\mathrm{b}}$ & $1.69^{\mathrm{a}}$ & $1.50^{\mathrm{b}}$ & $1.57^{\mathrm{B}}$ & $1.52^{\mathrm{c}}$ & $1.67^{\mathrm{a}}$ & $1.39^{\mathrm{de}}$ & $1.53^{\mathrm{B}}$ \\
\hline 50 & 50 & $1.50^{\mathrm{b}}$ & $1.66^{\mathrm{a}}$ & $1.48^{\mathrm{b}}$ & $1.55^{\mathrm{B}}$ & $1.46^{\mathrm{c}}$ & $1.61^{b}$ & $1.37^{\mathrm{de}}$ & $1.48^{\mathrm{C}}$ \\
\hline 75 & 25 & $1.48^{\mathrm{b}}$ & $1.64^{\mathrm{a}}$ & $1.48^{\mathrm{b}}$ & $1.53^{\mathrm{B}}$ & $1.43^{\mathrm{cd}}$ & $1.60^{\mathrm{b}}$ & $1.28^{\mathrm{fg}}$ & $1.44^{\mathrm{D}}$ \\
\hline 100 & Zero & $1.46^{\mathrm{b}}$ & $1.52^{\mathrm{b}}$ & $1.46^{\mathrm{b}}$ & $1.48^{\mathrm{C}}$ & $1.33^{\mathrm{ef}}$ & $1.55^{\mathrm{b}}$ & $1.26^{\mathrm{g}}$ & $1.38^{\mathrm{E}}$ \\
\hline Mean (OF) & & $1.53^{\mathrm{B}}$ & $1.64^{\mathrm{A}}$ & $1.52^{\mathrm{B}}$ & & $1.49^{\mathrm{B}}$ & $1.62^{\mathrm{A}}$ & $1.40^{\mathrm{C}}$ & \\
\hline
\end{tabular}

$\mathrm{OF}=$ organic fertilizer, $\min =$ mineral fertilizer, $\mathrm{FYM}=$ farmyard manure, $\mathrm{CH}=$ chicken manure, $\mathrm{CO}=$ compost .

\subsection{Hydraulic conductivity and available water}

Results in Figure (2a, b and c) showed that application of organic nitrogen fertilizers induced significant decreases in soil hydraulic conductivity $\left(\mathrm{K}_{\mathrm{h}}\right)$ and in the same time, progressive increases of the available water (AW \%). Considering the organic nitrogen types the following mean values of hydraulic conductivity could be arranged in the descending order FYM> Comp> CH. On the contrary, the available water increased in the following order CH> Comp> FYM, while increasing of hydraulic conductivity values decrease in available water values with mineral nitrogen fertilization compared to the initial stat. Ddecreasing in $K_{h}$ and increase in AW may be due to redistribution pore size (El-Fayoumy et al., 2001). The treatment of $100 \% \mathrm{~N}$ of $\mathrm{CH}$ manure was ascertained the maximum decreasing of $K_{h}(3.53 \mathrm{~cm} / \mathrm{h})$ and increasing AW (20.97\%) than other tested treatments.

\subsection{Tuber yield}

Table (7) showed the effect of nitrogen sources on tuber yield in both seasons. 
The differences among means values of dry tuber yield were significant in both seasons. The $\mathrm{CH}$ treatment increased the mean values of tuber yield by $10.26 \%$ $\& 8.77 \%$ in ${ }^{1 \text { st }}$ year and $9.7 \% \& 8.31$ in $2^{\text {nd }}$ year than the treatments of FYM and Comp. On the other hand, the superiority mean values of tuber yield were recorded in Chicken manure treatment which was 13.76 and 14.60 ton $\mathrm{fed}^{-1}$ in both $1^{\text {st }}$ and $2^{\text {nd }}$ seasons. Mean values of tuber yield at the rate $25 \% \mathrm{OF}+75 \% \mathrm{MIN}$, increased by $2.72,8.7$, and $3.4 \%$ in treatments of FYM, CH and comp. Consequently, the chicken manure treatment with rate of $25 \% \mathrm{OF}+75 \% \mathrm{MIN}$ is the best treatment on tuber yield at 1 st and 2nd seasons. These results in agreement by Abay and Tesfaye (2011), Balemi (2012) and Shiferaw (2014).

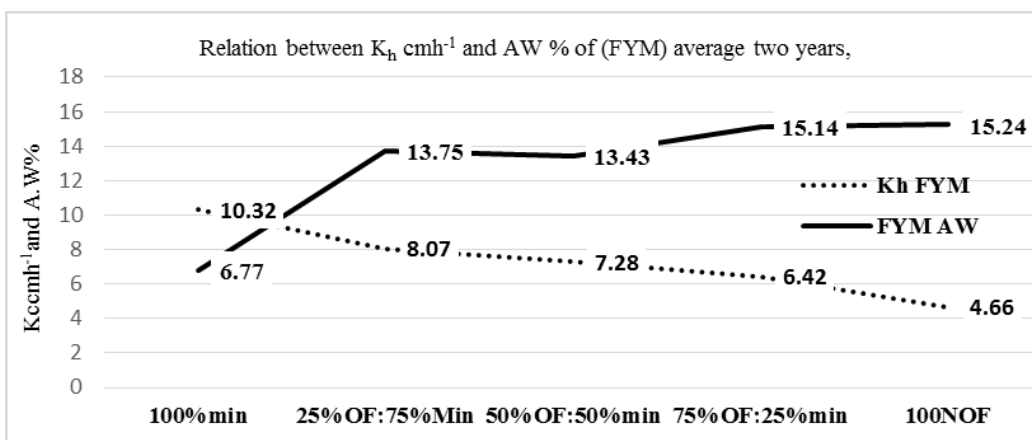

Figure (2-a): Effect of Farmyard manure (FYM) and its rates on hydraulic conductivity $\mathrm{K}_{\mathrm{h}} \mathrm{cm} \mathrm{h}^{-1}$ and available water AW \% average two years. OF= organic fertilizer, $\min =$ mineral fertilizer.

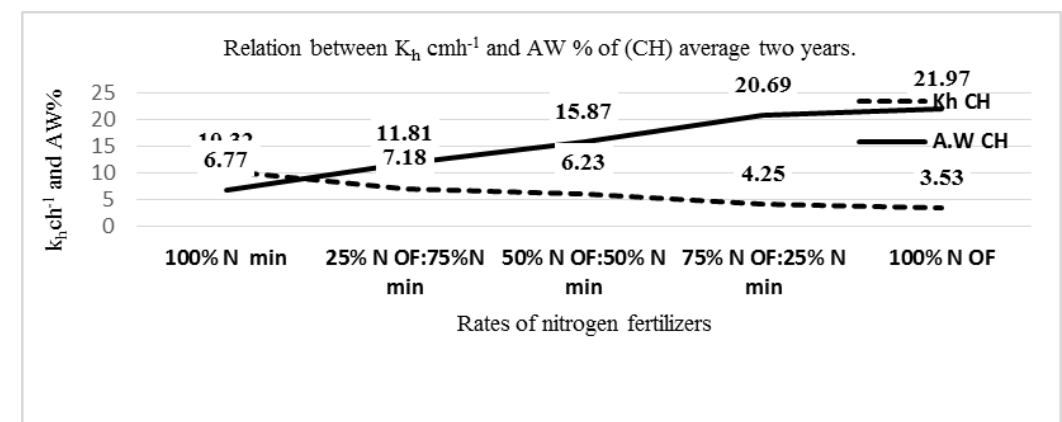

Figure (2-b): Effect of chicken manure $(\mathrm{CH})$ and its rates on hydraulic conductivity $\mathrm{k}_{\mathrm{h}} \mathrm{cmh}^{-1}$ and available water A.W\% average two years. $\mathrm{OF}=$ organic fertilizer, min $=$ mineral fertilizer. 


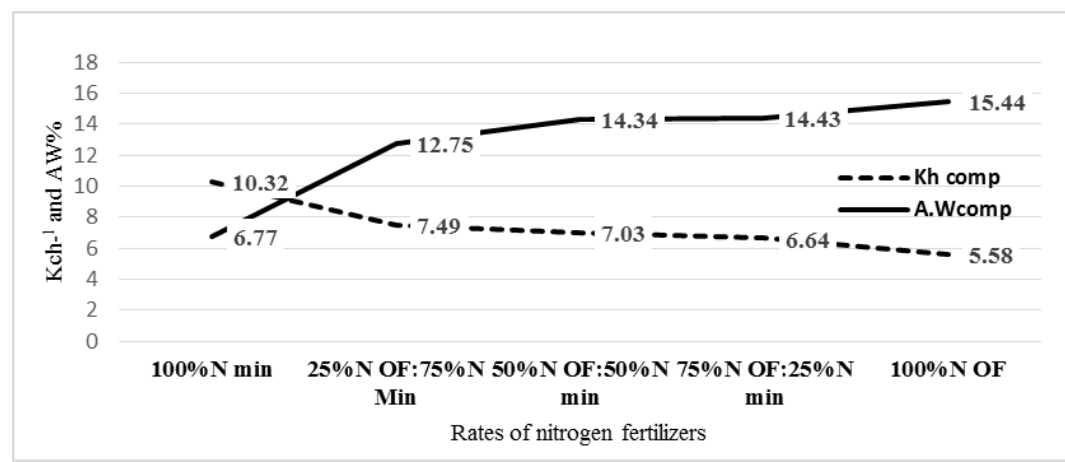

Figure (2-c): Effect of compost (CO) and its rates on Hydraulic conductivity $\mathrm{Kcmh}^{-1}$ and available water $\mathrm{AW} \%$ average two years. $\mathrm{OF}=$ organic fertilizer, $\min =$ mineral fertilizer.

Table (7): Effect of treatments on Potato yield during two winter of 2013/14 and 2014/15.

\begin{tabular}{|c|c|c|c|c|c|c|}
\hline \multirow{3}{*}{ Treatments } & \multicolumn{5}{|c|}{$2013 / 14$} & \multirow{3}{*}{$\begin{array}{c}\text { mean } \\
(\mathrm{OF})\end{array}$} \\
\hline & \multicolumn{5}{|c|}{ Organic N \%: mineral N \% } & \\
\hline & $0: 100$ & $25: 75$ & $50: 50$ & $75: 25$ & 100:0 & \\
\hline FYM & $14.70^{\mathrm{b}}$ & $15.10 \mathrm{~b}$ & $13.00 \mathrm{c}$ & $12.11 \mathrm{~d}$ & 7.50 & $12.48 \mathrm{~B}$ \\
\hline $\mathrm{CH}$ & $14.70^{\mathrm{b}}$ & $15.98 \mathrm{a}$ & $14.60 \mathrm{~b}$ & $13.14 \mathrm{c}$ & 10.40 & $13.76 \mathrm{~A}$ \\
\hline $\mathrm{CO}$ & $14.70^{\mathrm{b}}$ & $15.20 \mathrm{~b}$ & $13.10 \mathrm{c}$ & $12.40 \mathrm{c}$ & 7.85 & $12.65 \mathrm{~B}$ \\
\hline \multirow[t]{2}{*}{ mean rate } & $14.70^{\mathrm{B}}$ & $15.43 \mathrm{~A}$ & $13.57 \mathrm{C}$ & $12.55 \mathrm{D}$ & $8.58 \mathrm{E}$ & \\
\hline & & & $2014 / 15$ & & & \\
\hline FYM & $15.60^{\mathrm{b}}$ & $14.94 \mathrm{c}$ & $13.73 \mathrm{de}$ & $12.10 \mathrm{f}$ & 10.18 & $13.31 \mathrm{~B}$ \\
\hline Chicken manure & $15.60 \mathrm{~b}$ & $16.80 \mathrm{a}$ & $15.50 \mathrm{bc}$ & $14.10 \mathrm{~d}$ & 11.02 & $14.60 \mathrm{~A}$ \\
\hline Compost & $15.60 \mathrm{~b}$ & $15.20 b c$ & $13.50 \mathrm{de}$ & $12.50 \mathrm{ef}$ & 10.60 & $13.48 \mathrm{~B}$ \\
\hline mean rate & $15.60 \mathrm{~A}$ & $15.65 \mathrm{~A}$ & $14.24 \mathrm{~B}$ & $12.90 \mathrm{C}$ & $10.60 \mathrm{D}$ & \\
\hline
\end{tabular}

\subsection{Carbohydrate \% in tuber potato plant}

Table (8) showed that, different organic nitrogen fertilizer sources have significant influence on carbohydrate content in tubers in both seasons. Whereas, the mean values of carbohydrate content increased with applying chicken manure $\mathrm{CH}$ treatment by $1.7 \%$ and $1 \%$ and by $3.09 \%$ and $2.09 \%$ compared to the treatments of FYM and Comp in $1^{\text {st }}$ and $2^{\text {nd }}$ seasons, respectively. Also, mineral nitrogen fertilizer increased Carbohydrate \% in tubers compared to FYM and comp fertilization. It is clearly that, applied FYM or Compost reduced carbohydrate content compared to chicken manure $(\mathrm{CH})$ and mineral fertilizers. The obtained results are also in harmony with reported by (Ahmed et al., 2015).

\subsection{Specific gravity of tuber potatoes}

As shown in Table (9) the difference effects of organic nitrogen fertilizers on tuber specific gravity is significantly in both seasons. The specific gravity decreased from 1.066 by applied chicken manure $(\mathrm{CH})$ to 1.064 and $1.036 \mathrm{~g} / \mathrm{cm}^{3}$ by applied both of (FYM) and (Comp) in $1^{\text {st }}$ season, respectively. While in $2^{\text {nd }}$ season 
the different among mean values of tuber fertilizers in $1^{\text {st }}$ and $2^{\text {nd }}$ seasons. The specific gravity for all realized irregular superiority mean value was recorded for trend by increasing organic fertilizers $100 \% \mathrm{~N}$ mineral this data are in harmony ratio up to $100 \%$ mineral nitrogen with Shaheen et al. (2014).

Table (8): Effect of treatment on carbohydrate \% of potato tuber during two winter of 2013/14 and 2014/15.

\begin{tabular}{lcccccc}
\hline \multirow{2}{*}{ Treatments } & \multicolumn{5}{c}{$2013 / 14$} & \multirow{2}{*}{$\begin{array}{c}\text { Mean } \\
\text { OOF }\end{array}$} \\
\cline { 2 - 5 } & $0: 100$ & $25: 75$ & $50: 50$ & $75: 25$ & $100: 0$ & \\
\cline { 2 - 5 } & $20.10 \mathrm{~b}^{\mathrm{c}}$ & $20.32^{\mathrm{a}-\mathrm{c}}$ & $20.22^{\mathrm{bc}}$ & $19.95^{\mathrm{c}}$ & $19.00^{\mathrm{e}}$ & $19.92^{\mathrm{B}}$ \\
FYM & $20.10 \mathrm{~b}^{\mathrm{c}}$ & $20.57^{\mathrm{a}}$ & $20.20^{\mathrm{bc}}$ & $20.07^{\mathrm{bc}}$ & $19.48^{\mathrm{d}}$ & $20.08^{\mathrm{A}}$ \\
CH & $20.10 \mathrm{~b}^{\mathrm{c}}$ & $20.44^{\mathrm{ab}}$ & $20.22^{\mathrm{bc}}$ & $19.97^{\mathrm{c}}$ & $19.13^{\mathrm{e}}$ & $19.97^{\mathrm{AB}}$ \\
mean rate & $20.10^{\mathrm{BC}}$ & $20.44^{\mathrm{A}}$ & $20.21^{\mathrm{B}}$ & $20.00^{\mathrm{C}}$ & $19.20^{\mathrm{D}}$ & \\
\hline \multicolumn{5}{c}{$2014 / 15$} \\
FYM & $20.07 \mathrm{~b}-\mathrm{d}$ & $19.81 \mathrm{de}$ & $19.71 \mathrm{ef}$ & $19.45 \mathrm{f}$ & $19.04 \mathrm{~g}$ & $19.62 \mathrm{C}$ \\
CH & $20.07 \mathrm{~b}-\mathrm{d}$ & $20.84 \mathrm{a}$ & $20.30 \mathrm{~b}$ & $20.27 \mathrm{~b}$ & $19.91 \mathrm{c}-\mathrm{e}$ & $20.28 \mathrm{~A}$ \\
CO & $20.07 \mathrm{~b}-\mathrm{d}$ & $20.27 \mathrm{~b}$ & $20.17 \mathrm{bc}$ & $19.51 \mathrm{f}$ & $19.44 \mathrm{f}$ & $19.89 \mathrm{~B}$ \\
Mean (rate) & $20.07 \mathrm{~B}$ & $20.31 \mathrm{~A}$ & $20.06 \mathrm{~B}$ & $19.74 \mathrm{C}$ & $19.46 \mathrm{D}$ & \\
\hline \multicolumn{1}{c}{ OF=organic fertilizer, FYM= farmyard manure, CH= chicken manure, CO= compost. }
\end{tabular}

Table (9): Effect of treatments on specific gravity of Potato plant after two winter of 2013/14and 2014 /15.

\begin{tabular}{|c|c|c|c|c|c|c|}
\hline \multirow{3}{*}{ Treatments } & \multicolumn{5}{|c|}{$2013 / 14$} & \multirow{3}{*}{$\begin{array}{c}\text { Mean } \\
(\mathrm{OF})\end{array}$} \\
\hline & \multicolumn{5}{|c|}{ Organic N \%: mineral N \% } & \\
\hline & $0: 100$ & $25: 75$ & $50: 50$ & $75: 25$ & $100: 0$ & \\
\hline FYM & $1.050^{\mathrm{b}}$ & $1.080 \mathrm{ab}$ & $1.080^{\mathrm{ab}}$ & $1.080^{\mathrm{ab}}$ & $1.03^{\mathrm{b}}$ & $1.064^{\mathrm{A}}$ \\
\hline $\mathrm{CH}$ & $1.050^{\mathrm{b}}$ & $1.070 \mathrm{ab}$ & $1.060^{\mathrm{b}}$ & $1.030^{\mathrm{b}}$ & $1.12^{\mathrm{a}}$ & $1.066^{\mathrm{A}}$ \\
\hline $\mathrm{CO}$ & $1.050 \mathrm{~b}$ & $1.020 \mathrm{~b}$ & $1060^{\mathrm{b}}$ & $1.030^{\mathrm{b}}$ & $1.02^{\mathrm{b}}$ & $1.036^{\mathrm{B}}$ \\
\hline \multirow[t]{2}{*}{ mean (rate) } & $1.050^{\mathrm{A}}$ & $1.057^{\mathrm{A}}$ & $1.067^{\mathrm{A}}$ & $1.047^{\mathrm{A}}$ & $1.057^{\mathrm{A}}$ & \\
\hline & \multicolumn{5}{|c|}{$2014 / 15$} & \\
\hline FYM & $1.040^{\mathrm{b}}$ & $1.040^{\mathrm{b}}$ & $0.990^{\mathrm{c}}$ & $1.040^{\mathrm{b}}$ & $1.040^{\mathrm{b}}$ & $1.030^{\mathrm{A}}$ \\
\hline $\mathrm{CH}$ & $1.500^{\mathrm{a}}$ & $1.020^{\mathrm{bc}}$ & $1.030^{\mathrm{bc}}$ & $1.010^{\mathrm{bc}}$ & $1.040^{\mathrm{b}}$ & $1.120^{\mathrm{A}}$ \\
\hline $\mathrm{CO}$ & $1.020^{\mathrm{bc}}$ & $1.010^{\mathrm{bc}}$ & $1.040^{\mathrm{b}}$ & $0.990^{\mathrm{c}}$ & $1.040^{\mathrm{b}}$ & $1.020^{\mathrm{B}}$ \\
\hline Mean (rate) & $1.187^{\mathrm{A}}$ & $1.023^{\mathrm{BC}}$ & $1.020^{\mathrm{BC}}$ & $1.013^{\mathrm{C}}$ & $1.040^{\mathrm{B}}$ & \\
\hline
\end{tabular}

$\mathrm{OF}=$ organic fertilizer, $\mathrm{FYM}=$ farmyard manure, $\mathrm{CH}=$ chicken manure, $\mathrm{CO}=$ compost.

3.11 The relationship between NO3-N ppm in potato tubers, total nitrogen in tuber and total $N \%$ in soil

Data presented in Figure ( $3 a, b$ and $c)$ show that the different types of organic nitrogen fertilizers sources realized regular trend on $\mathrm{N} \%$ in tubers in both seasons. However, the difference between FYM and $\mathrm{CH}$ and Comp was almost insignificant in both seasons. The maximum mean of $\mathrm{N} \%$ in tuber was $1.51 \%$ and $1.42 \%$ with chicken manure as organic nitrogen fertilizers in $1^{\text {st }}$ and $2^{\text {nd }}$ seasons, respectively. The equal mean values of $\mathrm{N}$ concentration for different organic nitrogen fertilizers sources may 
be due to almost equal quantities of nitrogen added during the experiments period. This data is that obtained by Ewulo et al. (2008). The opposite effect of increasing $\mathrm{OF}$ rates on $\mathrm{N} \%$ in tuber caused the positive effect of $\mathrm{NO}_{3}-\mathrm{N}$ ion concentration in tuber of potato. Data present in the Figure 3 showed that the increasing total $\mathrm{N} \%$ in both tuber and soil leads to increasing $\mathrm{NO}_{3}-\mathrm{N}$ ion in tuber potato up to the harmful concentration. Difference among organic nitrogen fertilizer sources addition on nitrate ion in tuber potato was high significantly in both seasons. Generally, the means values of nitrate ion decreased by applied Comp fertilizer by $20.16 \%$ and $13.7 \%$ compared to $\mathrm{CH}$ manure and FYM, respectively in $1^{\text {st }}$ season. Similar trend was observed in the $2^{\text {nd }}$ season since nitrate ion decreased by applied Comp fertilizer by $40.1 \%$ and $22.2 \%$ compared to $\mathrm{CH}$ manure and FYM, respectively. The NO3-N ion concentration was directly proportional to the total $\mathrm{N}$ in the tubers and in soil. This data was harmony with that reported by Abbas et al. (2011) and Worthington (2001).

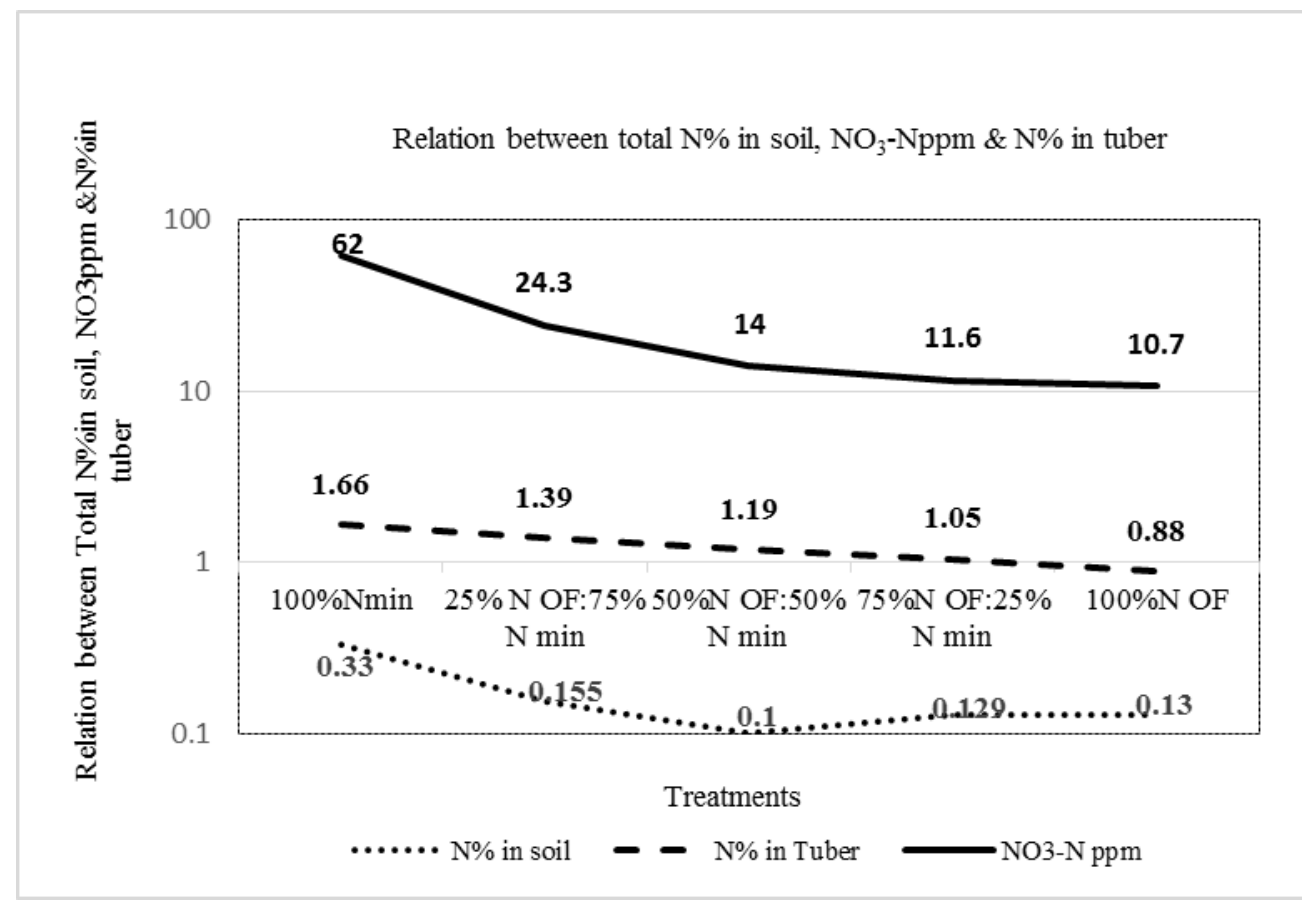

Figure (3-a): Relation between total N\% in soil and NO3-N ion and N\% in potato tuber by applying farmyard manure fertilizer. $\mathrm{OF}=$ organic fertilizer, $\min =$ mineral fertilizer. 


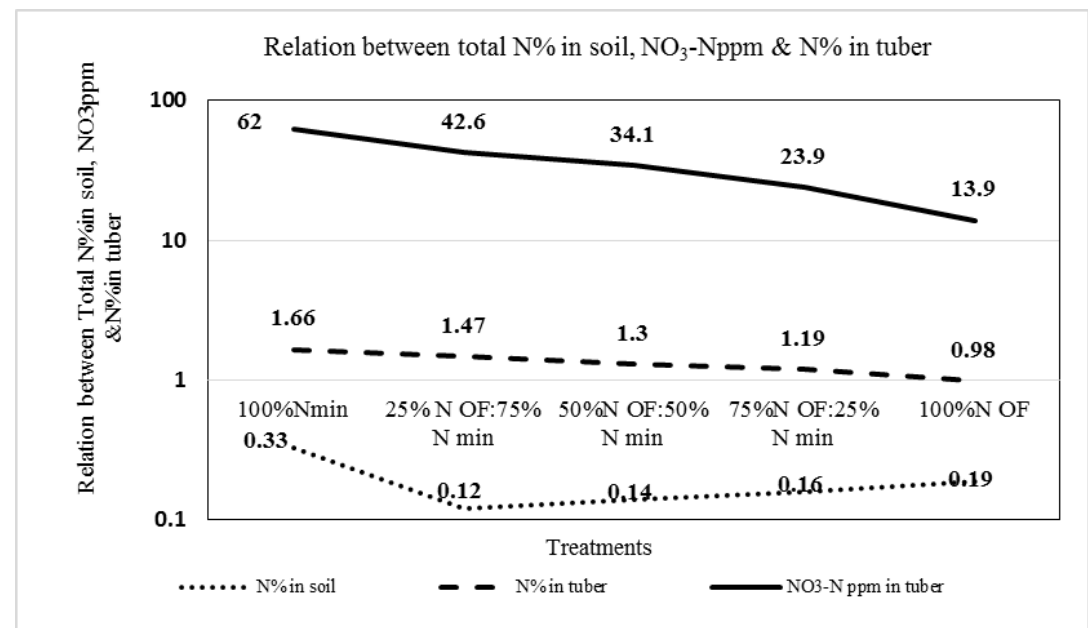

Figure (3-b): Relation between total $\mathrm{N} \%$ in soil and $\mathrm{NO}_{3}-\mathrm{N}$ ion and $\mathrm{N} \%$ in tuber by applying chicken manure fertilizer. $\mathrm{OF}=$ organic fertilizer, $\min =$ mineral fertilizer.

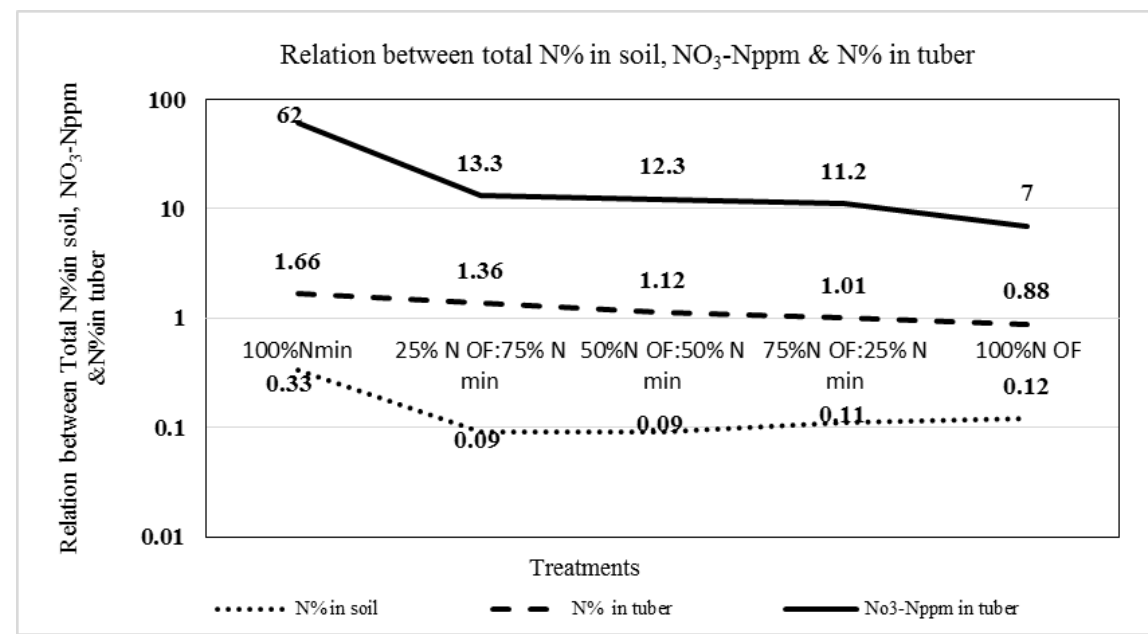

Figure (3-c): Relation between Total $\mathrm{N} \%$ in soil and $\mathrm{NO}_{3}-\mathrm{N}$ ion and $\mathrm{N} \%$ in tuber by applying Compost fertilizer. $\mathrm{OF}=$ organic fertilizer, $\min =$ mineral fertilizer.

\section{Conclusions}

It could be concluded that the integrated of organic and mineral nitrogen fertilizers are more important in potato fields. Since integrated OF with mineral fertilizer at level 25 OF: $75 \mathrm{~min}, 50 \mathrm{OF}: 50 \mathrm{~min}$ and 75 OF:25 min gave the moderated values of tuber yield and maintained soil health. While using $100 \%$ of mineral nitrogen gave the highest tuber yield production, at the same time, using $100 \%$ OF produce 
high quality tuber yield. Therefore, integrated organic and mineral nitrogen fertilizers contribute significantly towards maintaining and improving not only the potato productivity crop also improving chemical, physical properties of soil. In addition, they reduced the harmful effects of using nitrogen chemical fertilizers on tuber quality and soil. So, the application of organic and inorganic nitrogen fertilizers are considered the best option for sustaining soil fertility statues and leads to rationalize use of $\mathrm{N}$-mineral fertilizer for growing crop.

\section{References}

Abay, A. and Tesfaye, D. (2011), "Integrated application of compost and inorganic fertilizers for production of potato (Solanum tuberous L.)", Biology agriculture and Healthcare, Vol. 1 No. 2, pp. 2224-3208.

Abbas, M. A., Elamin, S. M. and Elamin, E. A. (2011), "Effects of chicken manure as component of organic production on yield and quality of eggplant (Solanum melongena L.) fruits", Journal of Science and Technology, Vol. 12 No. 4, pp. 1-8.

Ahmed Azza R., Bayoumi, M. A., Khalil, H. M. and Awaad, M. S. (2011), "Role of bio and organic fertilization on sustaining nitrogen requirements for rice production", Journal of Soil Sciences and Agricultural
Engineering - Mansoura University, Vol. 2 No. 1, pp. 43-57.

Ahmed Azza, R. (2013), "Study Influence of elemental sulphur compared with foliar spray fertilizers on productivity and maintenance calcareous soil", Nature and Science, Vol. 11 No. 3, pp. 26.

Ahmed Azza, R., Abbass, M. M. and ElFayoumy M. E. (2012), "Enhance soil quality and increasing yield of wheat crop followed by maize crop grown on calcareous soils", Nature and Science, Vol. 10 No.11, pp. 212-220.

Ahmed, A. A., Zaki M. F., Shafeek M. R., Helmy Y. I. and Abd El-Baky M. M. H. (2015), "Integrated use of farmyard manure and inorganic nitrogen fertilizer on growth, yield and quality of Potato (Solanum tuberosum L.)", International Journal of Current Microbiology and Applied Sciences, Vol. 4 No. 10, pp. 325-349.

Ashraful Islam, M., Islam Sumiya, Akter Ayasha, Rahman Md. H. and Nandwani, D. (2017), "Effect of organic and inorganic fertilizers on soil properties and the growth, yield and quality of tomato in Mymensingh, Bangladesh", Agriculture, Vol. 7 No. 3, pp. 18.

Balemi, T. (2012), "Effect of integrated use of cattle manure and inorganic fertilizers on tuber yield of potato in 
Ethiopia", Journal of Soil Science and Plant Nutrition, Vol. 12 No. 2, pp. 253-261.

Baniuniene A. and Zekaite V. (2008), "The effect of mineral and organic fertilizers on potato tuber yield and quality", AgronomijasVēstis (Latvian Journal of Agronomy), No. 11, pp.202-206.

Black, C. A. (1983), "Methods of Soil Analysis", Part I and II, Soil Science Society of America Inc. Public., Madison, Wisconsin, USA.

Black, C. A., Evans, D. D., White, J. L., Ensminger, L.E. and Clerk, F. E. (1965), "Methods of Soil Analysis", Part 1 and 2, American Society of Agronomy, Madison, USA.

Bremner, J. M. and Mulvaney, C. S. (1982), "Nitrogen-Total", in Page, A.L., Miller, R.H. and Keeney, D.R. Eds., Methods of soil analysis. Part 2. Chemical and microbiological properties, American Society of Agronomy, Soil Science Society of America, Madison, Wisconsin, USA, pp. 595-624.

El-Fayoumy, M. E. and Hammad, K. M. (2001), "Calcareous soil and sesame productivity improvement in relation to organic fertilization and frequency of irrigation", Journal of Agricultural Science, Mansoura University, Vol. 26 No. 3, pp. 18111832.
Ewulo, B. S., Ojeniyi, S. O. and Akanni, D. A. (2008), "Effect of poultry manure on selected soil physical and chemical properties, growth, yield and nutrient status of tomato", African Journal of Agricultural Research, Vol. 3, pp. 612-616.

Hati, K. M., Mandal, K. G., Misra, A.K., Ghosh, P. K. and Bandyopadhyay, K. K. (2006), "Effect of inorganic fertilizer and farmyard manure on soil physical properties, root distribution, and water-use efficiency of soybean in Vertisols of central India", Bioresource Technology, Vol. 97, pp. 2182-2188.

Herbert, D., Phillips, P. J. and Strange, R. E. (1971), "Chemical analysis of microbial cells. In microbiology, (Eds. Norris and Ribbons)", Vol. 58, Academic Press, New York, USA, pp. 204-344.

Hesse, P. R. (1971), "A Text Book of Soil Chemical Analysis". John Murry (Publisher) Ltd, 50 Albermarle Street, London.

MSTAT-C (1990), Micro Computer Statistical Program for Experimental Design and Analysis. Russell Freed (Ed.), MSTAT/Michigan State University, East Lansing, Michigan, USA.

Piper, C.S. (1950), "Soil and Plant Analysis", InterScience Publisher Inc., New York, USA. 
Ranganna, S. (1977), "Manual of Analysis of Fruit and Vegetable Products", Central Food Technological Research Institute Mysore, Cheluvamba Mansion, Opp. Railway Museum, Mysuru, Karnataka 570020, India

Richards, L. A. (1954), "Diagnosis and Improvement of Saline and Alkali Soils", Handbook No. 60, US Government Printing Office, US Department of Agriculture, Washington DC, USA.

Sadaf, J. and Khan, M. Q. (2011), "Impact of integrated nutrient management on tomato yield quality and soil environment", Journal of Plant Nutrition, Vol. 34, pp. 140149.

Shaheen, A. M., Rizk, F. A. and Abd ElRahman, N. G. (2014), "Growth, tubers yield and its nutritional value of potatoes as affected by cattle chicken and /or chemical nitrogen fertilizer", Middle East Journal of Agriculture Research, Vol. 3 No. 2, pp. 292-301.

Shaker Nesreen A. (2015), "Impact of some organic and inorganic nitrogen sources on potato crop grown in sandy soils", Master Thesis, Cairo University, Faculty of Agriculture, Giza, Egypt.

Shiferaw, B. (2014), "Effect of organic and inorganic fertilizer application and seedbed preparation on potato yield and soil properties on Alosols of chencha", Journal of Natural Sciences Research, Vol. 2 No. 8, pp. 123-132.

Smith, N. R. (1975), "Specific Gravity, Potato Processing", The AVI Publishing Company Inc., Westport, USA, pp. 43-66.

Tsegaye, G., Beyene, S. and Biazin, B. (2017), "Effect of organic and inorganic fertilizer application on soil phosphorous balance and phosphorous uptake and use efficiency of potato in Arbegona district, Southern Ethiopia", Journal of Fertilizers \& Pesticides, Vol. 8 No. 3, pp. 1000185.

Ulrich, A., Rierie, D., Hills, F. J., George, A. G., Moore, M. D. and Johnson, C. M. (1959), "Plant Analysis, a guide for sugar beet fertilization; Analytical methods for use in plant analysis", Berkeley, Calif.: Agricultural Experiment Station, pp. 335-337.

Worthington V. (2001), "Nutritional quality of organic versus conventional fruits, vegetables, and grains", Journal of Alternative and Complementary Medicine, Vol. 7 No. 2, pp. 161-173. 